\title{
THE ACQUISITION OF ENGLISH DATIVE ALTERNATION BY TURKISH ADULT LEARNERS OF ENGLISH
}

\author{
M. Pınar Babanoğlu
}

\begin{abstract}
Within the field of Second Language Acquisition (SLA) research, Interlanguage (IL) development has become an important component. In this respect, other related issues of IL development as native language factor for transfer situation, and effects of cross linguistic differences between languages have expanded the interest of the inquiry. This study investigates the IL development of Turkish adult learners of English in terms of the IL features they employed and L1 effect on their IL, regarding SLA theories. Primary purpose of the study is to examine IL grammar of Turkish adult learners of English considering similarities and differences between learners' acquisition process, the effect of Turkish as native language and learners' attitudes that can be accepted as language learning strategies. For this purpose, Dative alternation structures in English have been investigated through various learner data elicited from tests and corpus data. Research findings indicated that there is no significant difference in the use of dative structures between learners with different proficiency levels. On the other hand, overgeneralization and undergeneralization of some certain structures have been identified in terms of IL grammar properties and L1 transfer samples.
\end{abstract}

Key words: Second Language Acquisition, Interlanguage, Dative Alternation in English. 


\title{
INGILIZCE'DEKİ DOLAYLI NESNENIN İNGILIZZCE'Yİ İKINCII DİL OLARAK EDINEN TÜRK YETIŞKIINLER TARAFINDAN EDİNIMI
}

\begin{abstract}
$\ddot{O z e t}$
İkinci Dil Edinimi (IDE) araştırmaları kapsamında, aradil gelişimi önemli bir unsur haline gelmiş̧tir. Bu hususta, aradil gelişsimine bağgl diğer etmenler olan aradil üzerinde anadil faktörü ve diller arası dilbilimsel farklllıklar ilgi alanını genişletmişstir. Bu çallş̧ma İngilizceyi ikinci dil olarak öğrenen Türk yetişkinlerin aradil gelişimlerini ve sergiledikleri aradil özelliklerini IDE teorilerini dikkate alarak araştırmaktadır. Çalışmanın ana amacı Türk öğrenenlerin aradil gelişsimini ögrenenlerin dil edinimlerindeki benzerlik ve farklllıklar açısından incelemek ve anadil olan Türkçe’nin ögrrenenlerin aradilleri üzerindeki etkisini bir dil öğrenme stratejisi olarak değerlendirmektir. Bu amaçla İngilizcedeki dolaylı nesne yapıları, testler ve derlem verileriyle elde edilen çeşitli öğrenen verisi yoluyla incelenmişstir. Araştırma bulgularına göre, dolaylı nesne yapılarının kullanımlarında farklı Ingilizce seviyelerindeki ögrenenler arasında istatistiki açıdan anlamlı bir farklılık yoktur. Öte yandan, aradil özellikleri olarak ve anadil aktarımı adına bazı belli yapılarda aşırı genelleme ve yetersiz genelleștirme örneklerine rastlanmıştır.
\end{abstract}

Anahtar kelimeler: İkinci Dil Edinimi, Aradil, Ingilizcedeki dolaylı nesne. 


\section{INTRODUCTION}

In recent years, the scope of second language acquisition (SLA) has been expanded in the way that it encompasses various kinds of cognitive oriented views. The focus is firmly on identifying the nature and the source of underlying second language (L2) knowledge system, and on explaining developmental success and failure. In addition, the role of first language (L1) knowledge and the accessibility of universal constraints on linguistic structure and cognitive principles of language learning have been the contributors of the SLA studies (Andersen, 1983; Gass and Selinker, 1983; Kellerrman, 1984; Adjemian \& Liceras, 1984; Kellerrman \& Sharwood-Smith, 1986; Tarone, 1988; Felix, 1991; Hilles, 1991; Gass, 1996; White, 1989, 2000). Early meaning of SLA was a matter of overcoming the habits of L1 and there were obvious individual differences and native language effects (Larsen-Freeman \& Long, 1991). Afterwards, the idea of an innate language acquisition device (LAD) came out which was impressed with the learners' creative construction and sought explanations for the shared features of learners' interlanguage (IL) by pointing to the learning and communicative strategies they employed. IL system has a cognitive emphasis and focus on strategies that learners employ when learning a second language (Selinker, 1972). The role of L1 in the acquisition of L2 was re-examined under the scope of IL notion (Zobl, 1980a, 1980b) and the importance of L1 transfer was re-emphasized.

According to White \& Genesee (1996) the nature of linguistic system that L2 learners have and the aspects of their IL grammar are new focuses of current SLA theories, particularly of current Universal Grammar Theory. The question of whether L2 learners have the same mental representation of native speakers increased the importance of the nature of IL competence. In the light of these assumptions, related SLA studies by Mazurkewich (1984) and by Hawkins (1997) inspired and prompted to conduct the current study.

Selinker (1972) explained IL as L2 learners' own separate, creative and transformational linguistic system for developing a second language knowledge. Namely, IL is constructed by L2 learner on the basis of L2 input, and continue to develop by adding abstract rules, deleting or reconstructing rules, creating new strategies, i.e. IL generate itself as learners receive more input and revise their hypotheses about second language (Lightbrown \& Spada, 1999). This is a temporary grammar which has systematic and composed rules. These rules are the product of five main cognitive processes as:

1) Overgeneralisation: Some of the rules of the IL system may be the result of the overgeneralisation of specific rules and features of the target language. For exam- 
ple, putting a regular $-e d$ ending on an irregular verb, as in 'buyed' instead of 'bought'.

2) Transfer of Training. Some of the components of the IL system may result from transfer of specific elements via which the learner is taught the second language. For example, when a teacher's over-use of 'this' discourages the student from using 'that'.

3) Strategies of Second Language Learning. Some of the rules in the learner's IL may result from the application of language learning strategies "as a tendency on the part of the learners to reduce the TL [target language] to a simpler system" (Selinker,1972, p.219). Such as simplification, for example, when the learner 'simplifies' English so that all verbs may occur in the present continuous, yielding sentences as 'I'm hearing him'.

4) Strategies of Second Language Communication. IL system rules may also be the result of strategies employed by the learners in their attempt to communicate with native speakers of the target language. In order to communicate, learners sometimes avoid problematic items.

5) Language Transfer. Some of the rules in the IL system may be the result of transfer from the learner's first language.

The purpose of this particular study is to try to explain whether related assumptions would be a reasonable justification for the L2 acquisition of English dative alternation for Turkish adult learners. For this purpose, 50 intermediate and 50 advanced university level students were administered a grammaticality judgement task and a sentence construction task prepared by Hawkins (1987). In addition, Turkish International Corpus of Learner English (TICLE), which is a standard corpus and consists of the collection of Turkish adult learners' computerized performance in essay writing in English, analyzed in order to examine how Turkish learners acquire English dative alternation. This study aims to seek answers to the following research questions:

1. Do Turkish learners of English acquire [_ NP PP] constructions or [_ NP NP] constructions before?

2. Do L1 features negatively affect learners' use of the verbs requiring preposition for instead of to?

3. Does the learners' success with these forms increase gradually along with their proficiency levels? 


\section{Backround of the Study}

The conduct of this study was guided by studies of Mazurkewich (1984), and by Hawkins (1987) in respect of L2 acquisition of English dative alternation. In the former study, Mazurkewich (1984) applied the issue of markedness in terms of core/periphery distinction, which states that unmarked properties of language are related to core grammar and marked properties are to periphery. Mazurkewich hypothesized that; unmarked structures of core grammar will be acquired before the marked structures of periphery. In addition, dative structures provide a marked/unmarked variation in L2 acquisition. The distinction has been made as:

a) John gave a book to Mary (NP PP = unmarked)

b) John gave Mary a book (NP NP = marked)

In Mazurkewich's opinion, the NP PP prepositional complement in (1a) is considered to be part of core grammar and unmarked whereas the NP NP complement in (1b) is marked. For the study, 38 native speakers of Inuktitut, 45 native speakers of French and two groups of English native speakers as control groups has been tested. Grammaticality judgement task was used which contained marked and unmarked structures as well as distracter sentences. The results showed that French speakers preferred unmarked structures, both in the case of to and for. However, considering the fact that the dative structure in French is similar to the prepositional phrase in English, there might be a transfer of unmarked structures. Inuktitut speakers' were less persuasive in terms of accepting unmarked structures so that the same participants retested in a question formation in the next experiment (Mazurkweich, 1984b). This time, French speakers performed as predicted by Mazurkewich and produced more unmarked questions than Inuktitut speakers who produced more marked questions. Mazurkwich concluded that L2 learners will learn unmarked before marked. However, White (1989) questioned the Mazurkewich's study for insufficiency of statistical analyses of the data and stated that the behaviours of French speakers might showed an effect of transferring the unmarked structures of their L1 and Inuktituts preferred questions with preposition stranding which is a peripheral structure.

On the other hand, Hawkins (1987) re-examined the acquisition of dative alternation considered by Mazurkewish's order of sequence as: [NP PP] $\rightarrow$ [NP NP]. The participants were consisting of 10 native speakers of French who were university students of English. Hawkins replicated Mazurkewich's grammaticality judgement task by adding wider range of verbs. In addition, Hawkins used a sentence construction task. Results were confirmed the order of [NP PP] $\rightarrow$ [NP NP]. However, Hawkins stated that this developmental sequence conceals more complex set of stages in the acquisition of the dative alternation. Hence, these facts question the 
UG definition of markedness in explaining the L2 acquisition of dative alternation, according to him, the psycholinguistic notion of learning complexity seems propose a better account of the acquisition process.

\subsection{Dative Structures in English and Turkish}

Dative alternation in English pertain to the set of verbs subcategorizing for distinct complement types like prepositional phrases [_NP PP] and double object [_NP NP]. Many dative verbs such as give, sell, pay, pass, tell, build may appear with both complement types, for example give and build:

1) a) John gave [[the book ${ }_{\mathrm{NP}}$ [ [to Marypp]]

b) John gave [[Mary $\mathrm{NP}]$ [the book $\mathrm{NP}]]$

2) a) John built [[a house $\left.{ }_{\mathrm{NP}}\right]$ [for Mary $\left.\left.\mathrm{PP}\right]\right]$

b) John built [Mary ${ }_{N P}$ [ [a house ${ }_{N P}$ ]

(Hawkins, 1987 p.21)

The sentence pairs as in (1) and (2) are usually termed as the dative alternation. Although considered almost synonymous, these sentences are differentiated not only syntactically but also pragmatically. In sentence (2a) dative object is marked by a free morpheme whereas the dative object in sentence (2b) is marked by word order. On the other hand, there are other verbs such as address, deliver, demonstrate, describe, dictate, donate which are used only with [ _NP PP] complement:

3) a) Ted donated the money to UNICEF

* b) Ted donated UNICEF the money

(Hawkins, 1987 p.21)

Besides, verbs such as ask, cost, deny, envy, etc. are used with only [ NP NP] complement:

4) a) The teacher asked his students a question

* b) The teacher asked a question to his students

(Ely1ldırım, 1996 p.31)

These verbs which occur with only one type of compliment as opposed to the former group of verbs are referred as non-alternating verbs.

In Turkish, the dative alternation is marked with a case marker suffix attached to the 
head of a noun phrase in order to indicate the relationship of that noun phrase to other constitutions of the sentence (Göksel \& Kerslake, 2005). This inflectional suffix determines the direction of the action or the benefactor of the action. Both object positions are possible in Turkish, however, the case marker '-e', which sometimes becomes ' $-\mathrm{a}$ ' in accordance with the vowel harmony according to which the suffix should be in vocalic harmony with the preceding morphemes and the stem of the word. This situation can be exemplified as follows:

5) a) Ali kitab-1nı Mehmet-e verdi

Ali NOM his book ACC Mehmet DAT-to CASE MAR give PAST

Ali gave his book to Mehmet

b) Ali Mehmet-e kitab-1nı verdi

Ali NOM Mehmet DAT-to CASE MAR his book ACC give PAST

Ali gave Mehmet his book

6) a) Mine kitab-1 İlkay-a ald1.

Mine NOM the book ACC İlkay DAT-for CASE MAR buy PAST

Mine bought the book for Illkay

b) Mine İlkay-a kitab-1 aldı.

Mine NOM İlkay DAT-for CASE MAR the book ACC buy PAST

Mine bought the book for İlkay

\section{Data and Method}

In the present study, 100 Turkish subjects that have been chosen from the students at the English Language Teaching department of Faculty of Education at Çukurova University. In order to determine the English levels of the subjects, the University of Michigan Placement Test has been used. According to the results obtained from this test, the subjects have been divided into two groups as intermediate and advanced.

In order to measure and compare the performances of two groups of participants, two tasks to be involved including Grammaticality Judgement Task (GJT) and Sentence Construction Task (SCT). The first task is the GJT consisted of randomly ordered 70 sentences including alternating and non-alternating verbs were presented to the subjects and wanted to judge them grammatically or ungrammatically. In GJT sentences, there is a variety of thirty-five verbs which were considered to be involved in the English dative constructions. 
In Sentence Construction Task (SCT), participants were presented reduced sentences of the form: He throws Philip a ball, in which verb inflections and prepositions had not been given. They were then asked to inflect the verb for the simple past tense and to provide an appropriate preposition (to or for), only if they felt it was necessary to do so. Briefly, participants had to decide whether a verb could remain in the [_ NP NP] construction, or whether it required a prepositional object, and secondly they had to decide whether that preposition was to or for. As a distracter they were asked to inflect the verb for the past tense. For an additional measurement device, one way ANOVA was utilized.

In addition to GJT and SCT, a corpus based data utilized in terms of instrument of measurement. To increase the reliability and the strength of the data base for the investigation of dative alternation, Turkish International Corpus of Learner English (TICLE) is involved which consists of written data collected from argumentative essays of Turkish adult learners of English and consists of approximately 168,265 words. The results of TICLE analysis has been compared with the native form of the same kind of corpus named Louvain Corpus of Native English Essays (LOCNESS) which is a collection of the essays written by American university students who are native speakers (NS) of English and consists of approximately 169,422 words. The TICLE aims at making an outline of the IL of Turkish learners of English, namely non-native speakers (NNS) of English. The corpus was explored, for the specific purpose of this study, to see how the dative alternation in English the Turkish adult learners of English handle in their written performances. Turkish IL and American mother tongue corpora were investigated using WordSmith Tools software program which is designed for text analysis and manipulation that generates word lists from one or more texts by frequency and by alphabet. WordSmith can identify key words in a particular text and create a database of keywords to enable identification of keywords and associated words. In the study, dative verbs were tagged in both corpora before text analysis,for instance, verb give in Turkish and American corpora was tagged for its dative forms as in the example below:

...that the women don't give (npnp) him a son....

...people commit suicide to give (ppto) a message to the people.

All verbs which has been used in GJT and SCT tagged and calculated by WordSmith for their percentage and the frequency in respect of their usage in dative forms and assorted for their place in which kind of dative frame they have been used in and their total amounts were classified by their percentage and frequencies. The probability level of the frequencies is taken as $p \leq .05$, and the significantly underused and overused items are shown with an asterisk (*) in the tables. 


\section{Results and Discussion}

The GJT is a recognition task, that is, the subjects have been asked to indicate whether the sentences were correct or incorrect. This analysis has been done regarding the criterions and classifications that regulated by Hawkins (1987) who divided dative verbs in terms of their monosyllabic and polysyllabic base that may be a determining factor while acquiring the structure of dative alternation. The results obtained from the analysis of the GJT reveals that [ NP PP] constructions are acquired before [ NP NP] constructions. This can be clearly seen from Table 1 and Table 2 that each verb in [_ NP PP] construction was judged more often than the same verb in the [ NP NP] structure. The distinction between native/monosyllabic and non-native/polysyllabic verbs, which delimits alternating from non-alternating datives, expresses the situation of acquisitional process.

Table 1 Frequencies of Monosyllabic Verbs Used in GJT

\begin{tabular}{|lcccc|}
\hline Monosyllabic verbs & \multicolumn{2}{c|}{ Intermediate (total N= 50) } & \multicolumn{2}{c|}{ Advanced (total N=50) } \\
& {$\left[\begin{array}{c}\text { NP NP] } \\
\text { f }\end{array}\right.$} & {$\left[\begin{array}{c}\text { NP PP] } \\
\text { f }\end{array}\right.$} & f NP] & f \\
\hline send & 9 & 50 & 11 & 50 \\
lend & 16 & 50 & 17 & 46 \\
give & 20 & 49 & 24 & 50 \\
read & 44 & 50 & 45 & 41 \\
throw & 8 & 50 & 6 & 50 \\
serve & 16 & 50 & 23 & 50 \\
\hline
\end{tabular}

( $\mathrm{f}=$ frequency shows the number of subjects who judged the verb as in the above frame)

The results produced by our subjects are highly similar to those of Mazurkewich's (1984) and Hawkins' (1987). In terms of monosyllabic verbs which alternate, send and throw showed low frequency in $\mathrm{np} / \mathrm{np}$ frame. On the other hand, the verb read has been accepted by both groups as a verb allowing two frames as $n p / n p$ and np/pp. In the case of polysyllabic verbs, most of the verbs have been judged as alternating verb by both groups. For example, 45 subjects in intermediate and 40 subjects in advanced group have accepted the verb report as an alternating verb.

Table 2 Frequencies of Polysyllabic Verbs Used in GJT

\begin{tabular}{|lcccc|}
\hline Polysyllabic verbs & \multicolumn{2}{c|}{ Intermediate (total N= 50) } & \multicolumn{2}{c|}{ Advanced (total N=50) } \\
& {$\left[\begin{array}{c}\text { [ NP NP] } \\
\text { f }\end{array}\right.$} & [ NP PP] & [ NP NP] & [ NP PP] \\
\hline offer* & 17 & 50 & 20 & 50 \\
promise* & 14 & 44 & 16 & 44 \\
allow* & 26 & 6 & 26 & 11 \\
report & 45 & 50 & 40 & 49 \\
explain & 9 & 50 & 6 & 48 \\
propose & 26 & 50 & 29 & 50 \\
donate & 31 & 50 & 31 & 46 \\
dictate & 20 & 50 & 25 & 46 \\
despatch & 42 & 46 & 35 & 49 \\
\hline
\end{tabular}

( $\mathrm{f}=$ frequency shows the number of subjects who judged the verb as in the above frame); (*polysyllabic alternating verbs) 
In Table 3 below, the results of independent T-test which has been applied to measure the scores of GJT by two groups are shown. According to the results, $p$ value has been found as 0,316 . Therefore, there is no significant difference between two groups and they showed a similar success in GJT.

Table 3 Independent T-test Scores of GJT between Intermediate and Advanced Groups

\begin{tabular}{|l|c|c|c|c|c|}
\hline Groups & N & M & sd & t value & p value \\
1- ADVANCED & 50 & 51,44 & 3,52 & 1,009 & 0,316 \\
2- NTERMEDİATE & 50 & 50,68 & 3,99 & & \\
\hline
\end{tabular}

In terms of GJT, both groups suggested a close performance and normal distribution, i.e., development of both intermediate and advanced level of proficiency showed no difference in respect of judging the correctness and incorrectness of several dative structures.

In SC task, participants were presented reduced sentences of the form: He threw Philip a ball, in which verb inflections and prepositions had not been given. Participants reconstruct the sentence by regulating the past tense and using the correct dative form where necessary. Test results scanned in terms of correct and incorrect usage of the both groups of intermediate and advanced levels. The verbs in the answers regulated according to their having monosyllabic and polysyllabic base and frequencies of these verbs measured.

Table 4 Scores of the SCT of Dative Verbs in the Frames [_ NP PP]-to and [ NP PP]-for

\begin{tabular}{|c|c|c|c|c|c|c|}
\hline \multirow[t]{2}{*}{ Verb } & \multicolumn{3}{|c|}{ Intermediate $($ total $\mathbf{N}=\mathbf{5 0})$} & \multicolumn{3}{|c|}{ Advanced (total $\mathrm{N}=50$ ) } \\
\hline & $\begin{array}{c}\mathbf{f} \\
{\left[{ }_{-} \text {NP PP }\right] \text {-to }}\end{array}$ & $\begin{array}{c}\mathbf{f} \\
{\left[\mathrm{NP}_{\mathrm{NP}}\right]-\text { for }}\end{array}$ & $\underset{* \text { Incorrect }}{\mathbf{f}}$ & $\begin{array}{c}\mathbf{f} \\
{\left[\mathrm{NP}_{\mathrm{CP}}\right] \text {-to }}\end{array}$ & $\begin{array}{c}\mathbf{f} \\
{\left[{ }_{L} \text { NP PP }\right]-f o r}\end{array}$ & $\begin{array}{c}\mathbf{f} \\
* \text { Incorrect }\end{array}$ \\
\hline \multicolumn{7}{|c|}{$\begin{array}{l}\text { To verbs } \\
\text { (monosyllabic base) }\end{array}$} \\
\hline throw & 44 & 2 & 4 & 41 & - & 9 \\
\hline announce & 43 & 5 & 2 & 42 & 1 & 7 \\
\hline transfer & 37 & 2 & 11 & 45 & - & 5 \\
\hline give & 40 & 3 & 7 & 26 & 3 & 11 \\
\hline leave & 29 & 8 & 13 & 37 & 6 & 7 \\
\hline \multicolumn{7}{|c|}{$\begin{array}{l}\text { To verbs } \\
\text { (polysyllabic base) }\end{array}$} \\
\hline present & 29 & 7 & 14 & 38 & 4 & 8 \\
\hline donate & 23 & 18 & 9 & 19 & 29 & 2 \\
\hline read & 44 & 3 & 3 & 39 & 4 & 7 \\
\hline address & 42 & 2 & 6 & 43 & 4 & 3 \\
\hline despatch & 26 & 20 & 4 & 30 & 17 & 3 \\
\hline
\end{tabular}




\begin{tabular}{|c|c|c|c|c|c|c|}
\hline \multirow[t]{2}{*}{ Verb } & \multicolumn{3}{|c|}{ Intermediate (total $\mathrm{N}=50)$} & \multicolumn{3}{|c|}{ Advanced (total $\mathrm{N}=50$ ) } \\
\hline & {$\left[\begin{array}{c}\mathbf{f} \\
{\left[\mathrm{NP}_{\mathrm{PP}}\right]-\text { to }}\end{array}\right.$} & {$\left[\begin{array}{c}\mathbf{f} \\
{\left[\_ \text {NP PP }\right]-\text { for }}\end{array}\right.$} & *Incorrect & $\begin{array}{c}\mathbf{f} \\
{\left[\begin{array}{l}\mathrm{NP} \text { PP }]- \text { to }\end{array}\right.}\end{array}$ & {$\left[\begin{array}{c}\mathbf{f} \\
{[-N P \text { PP }]-f o r}\end{array}\right.$} & *Incorrect \\
\hline \multicolumn{7}{|c|}{$\begin{array}{l}\text { For verbs } \\
\text { (monosyllabic base) }\end{array}$} \\
\hline build & 11 & 39 & - & 2 & 46 & 2 \\
\hline spare & 12 & 33 & 17 & 17 & 30 & 3 \\
\hline save & 4 & 44 & 2 & 1 & 48 & 1 \\
\hline $\begin{array}{l}\text { For verbs } \\
\text { (polysyllab }\end{array}$ & & & & & & \\
\hline forgive & 1 & 36 & 13 & 2 & 42 & 6 \\
\hline accept & 1 & 35 & 14 & 2 & 42 & 6 \\
\hline reserve & 4 & 45 & 1 & 1 & 47 & 2 \\
\hline construct & 12 & 34 & 4 & 14 & 32 & 4 \\
\hline
\end{tabular}

*incorrect sentences with different prepositions such as until or into, etc.

According to the results of the sentence construction task (in Table 4), unlike Hawkins' (1987) findings, we observed that there is no distinction between the acquisition order of to-verbs and for-verbs. Subjects demonstrated similar performances in the relevant items of the task. Table 5 shows indepentent T-test scores of SCT by intermediate and advanced level groups, $p$ value has been measured as $p>$ 0,017 and indicated that there is no significant difference between two groups.

Table 5 Independent T-test Scores of SCT between Intermediate and Advanced groups

\begin{tabular}{|l|c|c|c|c|c|}
\hline Groups & N & M & sd & t value & p value \\
1- ADVANCED & 50 & 15,84 & 2,76 & 2,434 & 0,017 \\
2- NTERMEDİATE & 50 & 14,28 & 3,59 & & \\
\hline
\end{tabular}

When compared to results of the T-test of GJT, it can be seen that advanced group showed more successful performance in SCT. As far as the tasks are concerned, participants asked only judged the correctness of the sentences given in GJT. On the other hand, in SCT, participants asked to fix the grammar level and reconstruct the each sentence regulating the appropriate dative structure. Therefore, this difference of the difficulty levels of two tasks might cause performance change between two levels of proficiency. Hence, IL development can be seen as a result of this change.

The analysis of the corpus, the WordSmith software tool has been used to identify, calculate and compare the dative forms. After all verbs used with dative structure have been identified through the whole non-native speakers (NNS) corpus including Turkish data and in native speaker (NS) for American data, overall frequencies of each verb used in dative alternation were calculated and categorized under $\mathrm{pp} / \mathrm{to}$, $\mathrm{pp} /$ for and $\mathrm{np} / \mathrm{np}$. 
Table 6 below presents the total frequencies and structurally categorized verbs identified as dative verbs in Turkish data. Among the verbs which allow dative alternation which identified across corpora, the verbs with the highest frequencies in total usage are the preferred dative structures by the NNS. For example, the highest rated verb give which is used in both $\mathrm{PP} /$ to and $\mathrm{NP} / \mathrm{np}$ forms showed a high frequency in total as $26 \%$ among the all verbs used in whole corpus, $0,08 \%$ of this percentage has been used as dative verb with pp/to form and $0,05 \%$ has been as dative with $\mathrm{np} / \mathrm{np}$ form by Turkish data. On the other hand, another high frequent verb make in total which is used only with pp/for showed low level frequency and percent in dative use. Unlike the verb make, the verb prepare expressed a high amount usage as dative verb used only with $\mathrm{pp} /$ for although it has a normal distribution in total, mainly, 77 of 142 the verb prepare has been used as dative verb by Turkish data. As a structural group, the verbs used with $\mathrm{pp} /$ to forms generally have more high frequency and percentage than with $\mathrm{pp} /$ for and $\mathrm{np} / \mathrm{np}$ forms. Besides, the verbs which are used with both $\mathrm{pp} /$ to and $\mathrm{np} / \mathrm{np}$ structures such as give, show, explain, offer, pay and serve have been used more than the verbs used with both $\mathrm{pp} /$ for and $\mathrm{np} / \mathrm{np}$ forms such as buy.

Table 6 The Frequency and the Percentage Calculations of Verbs Used Totally and Categorically in NNS Corpus.

\begin{tabular}{|l|c|c|c|c|c|c|c|c|}
\hline \multicolumn{1}{|c|}{$\begin{array}{c}\text { Turkish } \\
\text { Data }\end{array}$} & \multicolumn{2}{c|}{ Total use } & \multicolumn{2}{c|}{$\begin{array}{c}\text { Dative use } \\
\text { pp/to }\end{array}$} & \multicolumn{2}{c|}{$\begin{array}{c}\text { Dative use } \\
\text { pp/for }\end{array}$} & \multicolumn{2}{c|}{$\begin{array}{c}\text { Dative use } \\
\text { np/np }\end{array}$} \\
\hline Verbs & f & \% & f & \% & f & \% & f & \% \\
\hline *give & 516 & 0,26 & 152 & 0,08 & & & 110 & 0,05 \\
\hline send & 36 & 0,02 & 20 & - & & & & \\
\hline *show & 137 & 0,07 & 12 & - & & & 8 & - \\
\hline transfer & 12 & - & 5 & - & & & & \\
\hline *explain & 32 & 0,02 & 2 & - & & & 1 & - \\
\hline *offer & 12 & - & 4 & - & & & 3 & - \\
\hline *pay & 79 & 0,04 & 2 & - & & & 3 & - \\
\hline throw & 5 & - & 2 & - & & & & \\
\hline announce & 3 & - & 1 & - & & & & \\
\hline leave & 49 & 0,02 & 2 & - & & & & \\
\hline present & 48 & 0,02 & 2 & - & & & & \\
\hline *serve & 15 & - & 1 & - & & & 1 & - \\
\hline donate & - & - & - & - & & & & \\
\hline prepare & 142 & 0,07 & & & 77 & 0,04 & & \\
\hline make 480 & 0,24 & & & 7 & - & & & \\
\hline create 86 & 0,04 & & & 8 & - & & & \\
\hline open 34 & 0,02 & & & - & - & & & \\
\hline build 25 & 0,01 & & & 1 & - & & & \\
\hline
\end{tabular}




\begin{tabular}{|l|c|c|c|c|c|c|c|c|}
\hline \multicolumn{1}{c|}{$\begin{array}{c}\text { Turkish } \\
\text { Data }\end{array}$} & \multicolumn{2}{c|}{ Total use } & \multicolumn{2}{c|}{$\begin{array}{c}\text { Dative use } \\
\text { pp/to }\end{array}$} & \multicolumn{2}{c|}{$\begin{array}{c}\text { Dative use } \\
\text { pp/for }\end{array}$} & \multicolumn{2}{c|}{$\begin{array}{c}\text { Dative use } \\
\text { np/np }\end{array}$} \\
\hline Verbs & f & \% & f & \% & f & \% & f & \% \\
\hline forgive & 3 & - & & & 1 & - & & \\
\hline save & 40 & 0,04 & & & 1 & - & & \\
\hline **buy & 71 & 0,04 & & & & - & - & - \\
\hline wish & 24 & 0,01 & & & & & 1 & - \\
\hline allow & 60 & 0,03 & & & & & 1 & - \\
\hline
\end{tabular}

* Verbs take both $\mathrm{pp} /$ to and $\mathrm{np} / \mathrm{np}$ forms

** Verbs take both $\mathrm{pp} /$ for and $\mathrm{np} / \mathrm{np}$ forms

When a similar process of frequency calculation applied to the American data in corpus, dative usage proportion presented an equal distribution. Hence, except for a few items, dative use proportion tends to be low than total use of a same verb. It can be realized that, in general, totally high rated dative verbs are not seem to occur in dative use. When compared with Turkish data, three structural groups as pp/to, $\mathrm{pp} /$ for and $\mathrm{np} / \mathrm{np}$ forms suggest a normal distribution among each other in American data. Both two data showed similarity in terms of the usage of $\mathrm{np} / \mathrm{np}$ forms in terms of frequency and percentage. However, there is a high proportion in the use of dative structures by Turkish data than American data. Correct use of verbs with [_NP PP/to] in both Turkish and native American data calculated according to their percentage and frequencies and then compared each other with Chi-square analysis.

Table 7 The Frequency and $\mathrm{X}^{2}$ Results of Each Correct Use of [NP_PP/to] Verbs in Corpus by Two Groups

\begin{tabular}{|c|c|c|c|c|c|c|}
\hline PP/FOR & \multicolumn{2}{|c|}{ Turkish } & \multicolumn{2}{|c|}{ American } & & \\
\hline Verbs & f & $\%$ & f & $\%$ & $X^{2}$ & $\mathbf{o} / \mathbf{u}$ \\
\hline give & 152 & 0,08 & 17 & 0,01 & $85,1 *$ & + \\
\hline send & 20 & - & 3 & - & 8,6 & + \\
\hline show & 12 & - & 3 & - & $\sim$ & $\sim$ \\
\hline transfer & 5 & - & 1 & - & $\sim$ & $\sim$ \\
\hline explain & 2 & - & 6 & - & $\sim$ & $\sim$ \\
\hline offer & 4 & - & 2 & - & $\sim$ & $\sim$ \\
\hline pay & 2 & - & 1 & - & $\sim$ & $\sim$ \\
\hline throw & 2 & - & - & - & $\sim$ & $\sim$ \\
\hline announce & 1 & - & - & - & $\sim$ & $\sim$ \\
\hline leave & 2 & - & - & - & $\sim$ & $\sim$ \\
\hline present & 2 & - & - & - & $\sim$ & $\sim$ \\
\hline serve & 1 & - & - & - & $\sim$ & $\sim$ \\
\hline donate & - & - & 1 & - & $\sim$ & $\sim$ \\
\hline
\end{tabular}

* statistically significant $(\mathrm{p} \leq 0,05) ;(\sim)$ no significant difference $\quad(+)$ overuse; $\quad(-)$ underuse 
According to the results in Table 7, verbs give and send revealed statistically significance across two groups. In addition, both two verbs are observed to be overused in Turkish data. Especially give + to has been used by both groups in the same ways in terms of PP/to structure. This item has been used in Turkish and native data as following:

Turkish (NNS) data: $\quad$......must give importance to its education faculties. ......give birth to this child.

Native (NS) data: ......give the baby to parents. .....give birth to an unwanted baby.

Table 8 The Frequency and $\mathrm{X}^{2}$ Results of Each Correct Use of [NP_PP/for] Verbs in Corpus by Two Groups

\begin{tabular}{|c|c|c|c|c|c|c|}
\hline PP/FOR & \multicolumn{2}{|c|}{ Turkish } & \multicolumn{2}{|c|}{ American } & \multirow[b]{2}{*}{$\mathbf{X}^{2}$} & \multirow[b]{2}{*}{$\mathbf{0} / \mathbf{u}$} \\
\hline Verbs & f & $\%$ & f & $\%$ & & \\
\hline prepare & 77 & 0,04 & - & - & $63,0 *$ & + \\
\hline make & 7 & - & 8 & - & $\sim$ & $\sim$ \\
\hline create & 8 & - & 4 & - & $\sim$ & $\sim$ \\
\hline open & - & - & 3 & - & $\sim$ & $\sim$ \\
\hline build & 1 & - & 1 & - & $\sim$ & $\sim$ \\
\hline forgive & 1 & - & - & - & $\sim$ & $\sim$ \\
\hline save & 1 & - & 2 & - & $\sim$ & $\sim$ \\
\hline buy & - & - & 2 & - & $\sim$ & $\sim$ \\
\hline
\end{tabular}

* statistically significant $(\mathrm{p} \leq 0,05) ;(\sim)$ no significant difference $(+)$ overuse; $(-)$ underuse

In Table 8 above, the correct use of [NP_PP/for] structure is illustrated according to the frequencies, percentages and Chi-square results for both groups. The verb prepare expressed a significant difference in Turkish data. As it can be seen, this item is high rated and overused in Turkish data while it is not identified in native data. Verb prepare been used by Turkish students as below:

.....prepare the students for the life.

.....prepare you for the job. 
Table 9 The Frequency and $\mathrm{X}^{2}$ Results of Each Correct Use of [NP_NP] Verbs in Corpus by Two Groups.

\begin{tabular}{|c|c|c|c|c|c|c|}
\hline \multirow{2}{*}{\begin{tabular}{|lc} 
& $\begin{array}{c}\text { NP/NP } \\
\text { verbs }\end{array}$ \\
Verbs & \\
&
\end{tabular}} & \multicolumn{2}{|c|}{ Turkish } & \multicolumn{2}{|c|}{ American } & \multirow[b]{2}{*}{$\mathbf{X}^{2}$} & \multirow[b]{2}{*}{$\mathbf{o} / \mathbf{u}$} \\
\hline & f & $\%$ & $\mathbf{f}$ & $\%$ & & \\
\hline give & 110 & 0,05 & 64 & 0,04 & $5,2^{*}$ & + \\
\hline show & 8 & - & 5 & - & $\sim$ & $\sim$ \\
\hline pay & 3 & - & 3 & - & $\sim$ & \\
\hline offer & 3 & - & 2 & - & $\sim$ & $\sim$ \\
\hline explain & 1 & - & - & - & $\sim$ & $\sim$ \\
\hline serve & 1 & - & - & - & $\sim$ & $\sim$ \\
\hline wish & 1 & - & - & - & $\sim$ & $\sim$ \\
\hline allow & - & - & 1 & - & $\sim$ & $\sim$ \\
\hline buy & - & - & 1 & - & $\sim$ & $\sim$ \\
\hline
\end{tabular}

* Statistically significant $(\mathrm{p} \leq 0,05) ;(\sim)$ no significant difference $(+)$ overuse; $(-)$ underuse

In respect of [NP_NP] forms, results revealed statistically significance only in the verb give $+\mathrm{np}$ with 5, 2 Chi-square values as in Table 9. It is clear that, give with NP structure has been used in Turkish data nearly two times more than native data so that it is overused. In both data, this item has been used as in the following sentences:

Turkish data: .....give him a son.

......give you much pain.

Native data: .....give them wisdom.

..... give students more education.

In Turish data, if students have made mistakes in the use of dative structures, for example, when they use $\mathrm{pp} /$ to against $\mathrm{pp} /$ for after a verb which should preceed $\mathrm{pp} /$ for structure or vice-versa, this is considered as an incorrect usage and identified as an error in the anlysis. The same categorial procedure is applied and first errors are individullay identified, then totally observed and measured. Naturally, no errors have been identified in the native data. 
Table 10 The Frequency and $\mathrm{X}^{2}$ Results of Total Correct Use of Verbs with Three Structures in Corpus by Two Groups.

\begin{tabular}{|l|cc|cc|cc|}
\hline \multirow{2}{*}{$\begin{array}{c}\text { datives } \\
\text { total }\end{array}$} & \multicolumn{2}{|c|}{ Turkish } & \multicolumn{2}{c|}{ American } & \multicolumn{2}{c|}{} \\
\cline { 2 - 8 } & f & \% & f & \% & \multicolumn{1}{c|}{$\mathbf{X}^{\mathbf{2}}$} & o/u \\
\hline $\mathrm{PP} / \mathrm{to}$ & 205 & 0,10 & 37 & 0,02 & $89,0^{*}$ & + \\
$\mathrm{NP} / \mathrm{np}$ & 127 & 0,06 & 70 & 0,05 & $4,9^{*}$ & + \\
$\mathrm{PP} /$ for & 95 & 0,05 & 22 & 0,01 & $33,0^{*}$ & + \\
\hline
\end{tabular}

* statistically significant $(\mathrm{p} \leq 0,05) ;(\sim)$ no significant difference $(+)$ overuse; $(-)$ underuse

All three structural categories as correctly used verbs with $\mathrm{pp} / \mathrm{to}, \mathrm{pp} /$ for and $\mathrm{np}$ forms are calculated and compared within the two groups by Chi-square in Table 10. When we consider the frequencies, it is clear that the most used form as a dative structure is the ones made by $\mathrm{pp} / \mathrm{to}$ in Turkish data. However, native group have not used it as much as Turkish group, so there is a statistical significance occurred as $\mathrm{X}^{2} 89,0$ and $\mathrm{pp} /$ to forms have been overused. It can be claimed that Turkish students seem to use pp/to forms mostly than natives, even when compared all three structures each other. So, $\mathrm{pp} /$ to form is the most common dative structure for Turkish data. Other two categories showed significance too, especially $\mathrm{np} / \mathrm{np}$ forms have a high proportion of correct use although there is not such a structure in Turkish language.

Table 11 The Frequencies of Total Incorrect Use of Verbs with Three Structures in Corpus by Two Groups.

\begin{tabular}{|l|cc|cc|cc|}
\hline \multirow{2}{*}{$\begin{array}{c}\text { errors } \\
\text { total }\end{array}$} & \multicolumn{2}{|c|}{ Turkish } & \multicolumn{2}{c|}{ American } & & \\
\cline { 2 - 8 } & f & \% & f & \% & $\mathbf{X}^{\mathbf{2}}$ & o/u \\
\hline $\mathrm{PP} /$ for & 31 & 0,02 & - & - & $24,3^{*}$ & \\
$\mathrm{NP} / \mathrm{to}$ & 8 & - & - & - & $4,2^{*}$ & \\
$\mathrm{PP} / \mathrm{np}$ & 7 & - & - & - & $4,2^{*}$ & \\
\hline
\end{tabular}

* statistically significant $(\mathrm{p} \leq 0,05)$

In Table 11, a total error analysis of both three structural groups suggests that incorrect datives made only in pp/for as it is explained below. Despite the fact that there are no errors occurred in native American data, the $\mathrm{X}^{2}$ results are considered because of yielding significance when two data groups are compared. Specifically, $\mathrm{pp} /$ for items shows significance mostly because of the incorrect use of prepare $+\mathrm{pp} /$ for structure. There is not much significance among the errors except for the verb prepare with a high rate. There was an overuse which was observed in 
the correct use of prepare+pp/for. Interestingly, incorrect rate of verb prepare revealed a high proportion. Turkish students generally used this item in the corpus as:

prepare the students $\boldsymbol{t o}^{*}$ real life.

........prepare us to* real world.

As it can be seen, Turkish students have used prepare with the preposition -to against -for. For this reason, although this item has been used correctly with a high rate, Turkish students seem to overgeneralize in the use of prepare+pp/for. Another fact that students have made mistakes in the $\mathrm{pp} /$ for against $\mathrm{pp} /$ to but not in viceversa, in other words, there is no significant errors in pp/to datives. We can claim that, if Turkish students have made mistakes in using to against for, there might be an overgeneralization in their IL grammar. These kind of errors may give an idea of Turkish students overgeneralize the $\mathrm{pp} /$ to forms which can be considered to be common and closest form to Turkish language.

In general, as far as NNS corpus by Turkish data and NS corpus by American data concerned, two different group analyses showed differences both in item by item use and total use of dative structures. Considering the overall results, it can be claimed that IL development shows influence from native language features as overgeneralization or transfer of training.

\section{CONCLUSION}

This study attempts to examine the possibility of whether Turkish adult learners' ILs are affected by their L1 or they have access to linguistic universals (UG) while acquiring English dative alternation and to investigate their common tendencies in terms of IL features they employed. Research questions of the study were evaluated considering the results of the data analysis.

1- Do Turkish learners of English acquire [ NP PP] constructions or [ NP NP] constructions before?

Hawkins (1987) suggested that, according to his findings, Mazurkewich's discovery that [ NPP PP] construction is acquired before [_NP NP] construction is not the only factor involved in the acquisition of the dative alternation by L2 learners and there is an acquisitional sequence which provides learners accept lexical NP's in the _NP NP frame, but not all verbs. In fact, Hawkins (1987) pointed that, learners assume to the same underlying surface structure of dative alternation until there is a positive evidence on the contrary, in other words, learners test out the features of the learnability constraints. 
According to findings of the present study, it can be claimed that, Turkish adult learners of English seem to present a similar approach as Hawkins (1987) emphasized in terms of the acquisition of dative structures. Corpus analysis showed that there is no problem in the use of [_NP NP] forms. However, it should be considered that, the total amounts of [ NP PP] forms used by Turkish learners of English presented overuse than [_NP NP] forms.

2- Do positional L1 features negatively affect learners' use of the verbs requiring preposition for instead of to?

We observe some L1 interference because the results provided clear evidence of L1 interference regarding the issue of identification of the case marker with the prepositional complement structure in the target language. Learners accepted the use of the preposition to instead of for when the verb is to be used with for and vice versa in the following item:

prepare : She prepare her friends a Chinese meal.

This effect might be arisen from the learners' linguistic knowledge of Turkish dative structure which is determined by $-e$ and $-a$ suffixes. In their IL grammar, learners might have associated these two suffixes with -to form in English more than other two forms so that they might have showed a tendency of using -to inappropriately. This fact may give an opinion to explain the L1 transfer indicators that have been founded in the results.

3- Does the learners' success with these forms increase gradually along with their proficiency levels?

The results showed that there is no significant difference between the groups of intermediate and advanced level of proficiency. Low level of difference occurred in the Sentence Construction Task in the favour of advanced group, however, this may not be a criterion for the development of IL grammar of both groups.

In general, the results showed that the use of case marker which is same as the preposition used in the English dative alternation gave rise to confusion and learners overgeneralised and/or undergeneralised certain structures by relying on the use of the case marker in the native language. The results implied that learners should be taught the difference between case marker in the mother tongue and the use of preposition in the target language at all levels of proficiency. Furthermore, learners should be taught the use of for-datives through indicating the difference between the use of to-datives and for datives. Finally, learners' attention should be drawn to the use of structure in discourse to prevent the possible confusion caused by the use of case marker in the mother tongue, as well. 


\section{Reference}

Adjeman, C.\& Liceras, J. (1984). Accounting for adult acquisition of relative clauses: Universal Grammar, L1 and structuring the intake. In F. Eckman, et al. (Ed.) The competence performance issue in second language acquisition: a debate. Amsterdam,:Kruwer .

Andersen, R. (1983). Transfer to somewhere. In S. Gass and L. Selinker (Eds.) Language transfer in language learning (pp.177-201). MA: Newbury House, Rowley.

Ellis, R. (1985). Understanding second language acquisition. Oxford : Oxford University Press.

Ellis, R. (1994). The Study of second language acquisition. Oxford: Oxford University Press.

Ellis, R. (1997). Second language acquisition. Oxford : Oxford University Press.

Elyıldırım, S. (1996). Acquisition of the English dative alternation by Turkish learners, Paper presented in the fifth Manchester Postgraduate Linguistics Conference, Manchester, The University of Manchester.

Felix, S. (1991). The accessibility of universal grammar in second language acquisition. In L. Eubank (Ed.) Point counterpoint: universal grammar in the second language. Amsterdam: John Benjamins

Gass, S.M.\& Selinker, L. (1983). Language transfer in language learning. MA: Rowley, Newbury House.

Gass, S.M. (1996). Second language acquisition and linguistic theory: the role of language transfer. In: W.R., Ritchie and T.J. Bhatia (Eds.), Handbook of Second Language Acquisition, (pp:.317-345) San Diego : Academic Press.

Granger, S. (Ed.) (1998). Learner English on Computer. London and NY: Longman.

Göksel, A.\& Kerslake, C. (2005). Turkish.. Routledge: NY.

Hawkins, R. (1987). Markedness and the acquisition of the English dative alternation by L2 speakers. Second Language Research 1(3), 20-55.

Hilles, S. 1991. Access to Universal Grammar in second language acquisition. In Eubank, L. (Ed.) Point Counterpoint: Universal Grammar in the Second Language (pp.305338). Amsterdam: John Benjamins.

Kellerrman, E.1984. The empirical evidence for the influence of the L1 in interlanguage. In: Davies, A., Criper, C. and Howatt, A. (Eds.) Interlanguage (pp.98-122). Edinburg: Edinburg University Press

Kellerrman, C. \& Sharwood-Smith, M. (1986). Cross-linguistic influence in second language acquisition. Pergamon, NY .

Larsen-Freeman, D.\& Long, M. (1991). An introduction to second language acquisition research. London: Longman.

Lightbrown, P.M. \& Spada, N. (1999). How languages are learned. Oxford University Press, Oxford. 
Mazurkewich, I. (1984b). The acquisition of the dative alternation by second language learners and linguistic theory. Language Learning, 34, 91-109.

Mazurkewich, I. \& White, L. (1984). The acquisition of dative alternation: unlearning overgeneralizations. Cognition, 16, 261-283.

Selinker, L. (1992). Rediscovering interlanguage. NY: Longman.

Selinker, L. (1972). Interlanguage. International Review of Applied Linguistics, 10, pp.209231.

Tarone, E.E. (1988). Variation and second language acquisition. London: Edward Arnold.

White, L. (2000). Second language acquisition: From initial to final state. In J. Archibald (Ed.) (June), Second Acquisition and Linguistic Theory (pp.130-155). Oxford: Blackwell.

White, L. (1989). Universal grammar and second language acquisition. Amsterdam : John Benjamins.

White, L. (1986). Implications of parametric variation for adult second language acquisition: an investigation of the pro-drop parameter. In V.J. Cook (Ed.), Experimental Approaches to second Language Acquisition ( pp.55-72). Oxford: Pergamon.

White, L. \& Genesee, F. (1996). How native is near-native? The issue of ultimate attainment in adult second language acquisition. SLA, 12, 238-265.

Zobl, H. (1980a). The formal and developmental selectivity of L1 influence on L2 acquisition. Language Learning, 30(1), 43-57.

Zobl, H. (1980b). Developmental and transfer errors: Their common bases and (possibly) differential effects on subsequent learning. TESOL Quarterly,14(4), 469-479. 